\title{
CITY BRANDING KOTAGEDE Heritage Travelling Diary
}

\author{
Kadek Primayudi \\ Desain Komunikasi Visual \\ Fakultas Seni Rupa ISI Yogyakarta \\ kadekprimayudi@gmail.com
}

\begin{abstract}
Kotagede is one of the cities in Java that uses the basic principle of the philosophy of "Catur Gatra Tunggal" which is an amalgamation of the four elements into a single unit. Catur Gatra Tunggal consists of Keraton (palace) as the center of power authority, city squares as the center of public rituals, mosque as the center of worship and market as the trading center fused in one area.

Kotagede has the potential of heritage such as handicrafts, works of culinary, distinctive art, and the tomb of King that can be a strength of Kotagede brand image built in the target audience's mind. This potential has been surviving for generations to the present. Kotagede can be offered to the target audience by introducing the city through the promotion of activities involving the stakeholders such as the local government and community of Kotagede Yogyakarta.

The communication strategy undertaken in this design is city branding efforts of Kotagede by juxtaposing the potential heritage of the idea of social story videos in the form of diary on daily journal of travel in exploring Kotagede with provided benefits are peace and comfort.
\end{abstract}

Keywords: Kotagede, City Brand, Catur Gatra Tunggal, Heritage, Video Diary.

Relevance to Visual Communication Design Practice: This social video diary was designed to be a communication strategy as a city brand method.

\section{PENDAHULUAN}

Pendokumentasian hasil pengamatan terhadap kondisi yang baru menjadi suatu kenangan serta menarik ketika diceritakan kepada keluarga maupun orang lain. Ketika seseorang mendokumentasikan aktivitasnya di daerah tertentu dan mempublikasikannya, nama daerah tersebut dapat menjadi bahan pembicaraan sehingga akan dikenal bahkan mendatangkan teman baru untuk berkomentar dan berdiskusi.

Iswati (2009:2), Kotagede menjadi ibu kota Mataram sejak tahun 1586 dan berkembang menjadi kota para abdi dalem karya, tukang keraton hingga menjadi pusat industri dan perdagangan pribumi pada masa pemerintahan Panembahan Senopati tahun 1903 yang memiliki konsep tata ruang Catur Gatra Tunggal yang terdiri dari keraton, alunalun, masjid dan pasar. Perpindahan keraton sekarang menyebabkan Kotagede menjadi kawasan penting bagi sejarah kota Yogyakarta, dan meninggalkan bangunan sejarah dari konsep tata ruang Catur Gatra Tunggal yang masih bertahan yaitu komplek Makam Raja Mataram dan pasar.

Kotagede juga dikenal dengan sebutan Sargede (Riyadi, 2001: 1). Hal ini juga diungkapkan oleh Muhammad Natsir dalam wawancara pada 4 Februari 2012 bahwa orang Kotagede sering menyebut dirinya Wong Sargede. Sargede yang merupakan 
penyingkatan nama oleh warga dari kata nama Pasar Gede, tidak hanya menunjukkan suatu tempat tujuan aktivitas warga ke sebuah pasar. Ketika warga menyebut akan pergi ke Sargede, bisa berarti ke sebuah tempat di kawasan Kotagede seperti rumah teman, rumah paman atau rumah saudara sehingga nama pasar menjadi ikon yang memiliki makna atau nilai baru. Makna atau nilai-nilai baru yang dibawa oleh warga dapat membangun citra Kotagede. Nilai sejarah dan nilai kehidupan warga dahulu menjadi sebuah warisan (heritage) bagi generasi sekarang dan yang akan datang.

Heritage Kotagede memberi daya tarik bagi masyarakat untuk mengamati dan mendokumentasikan bangunan-bangunan bersejarah. Warga Kotagede yang aktif mendokumentasikan Kotagede adalah Sukarja dan Muhammad Natsir. Sukarja yang berasal dari kampung Jagungan, Kotagede, memulai aktifitas pendokumentasiannya sekitar tahun 1950 melalui media foto. Objek kawasan Kotagede beserta aktivitas warganya, diminati oleh Sukarja sebagai upaya untuk menambah teman serta menjalin persaudaraan dengan warga sekitar Kotagede. Berdasarkan pemaparan Sukarja dalam wawancara di tempat tinggalnya, 19 Juli 2012, foto-foto hasil pendokumentasiannya tersebar ke berbagai kampung serta menjadi koleksi perpustakaan Kotagede yang sekarang berada di kampung Pekaten, Kotagede. Namun kurangnya pengetahuan dan pengalaman Sukarja dalam penyimpanan dokumen, menyebabkan hilangnya foto-foto dokumen hasil dari kamera yang masih menggunakan rol film.

Muhammad mendokumentasikan berbagai aktivitas masyarakat di sekitar Kotagede dalam bentuk foto mulai ditekuni sejak usia 20 tahun hingga sekarang. Berbagai hal yang dinilai menarik di Kotagede didokumentasikan dan dipublikasikan kepada teman-temannya melalui media jejaring sosial facebook sejak tahun 2008.

Perkembangan dunia jejaring sosial semakin memudahkan masyarakat untuk mempublikasikan segala pendokumentasian aktivitas dan rekaman penglihatannya melalui foto dan video. Pendokumentasian tersebut juga dapat menunjukkan keberadaan seseorang pada saat itu dengan segala cerita yang menarik yang dapat menjadi bahan bertukar (share) pengalaman. Ditambah dengan dukungan teknologi dalam merekam dan men-share, masyarakat pengguna teknologi tersebut dipermudah untuk membagikan pengalamannya dari berbagai daerah yang terkadang sulit dijangkau, misalnya melalui handphone maupun smartphone.

Memperkenalkan citra Kotagede merupakan upaya dalam branding Kotagede. Memperkenalkan kawasan perkotaan yang memiliki keunikan masing-masing untuk membangun citranya secara terpadu disebut city branding. Kotagede merupakan kawasan kecil di Yogyakarta yang dapat dilakukan branding dari potensi-potensi yang dimiliki. Dalam city brand, tentu ada hal lain yang bisa ditawarkan kepada wisatawan selain bangunan fisik yang ada di Kotagede. Nilai sejarah serta keberagaman aktivitas kehidupan masyarakatnya menjadi kekuatan dalam memperkenalkan Kotagede sehingga menjadi ciri tersendiri bagi Kotagede. Pengalaman jelajah (travelling) heritage Kotagede, memberikan inspirasi dalam studi 
visual kemudian diungkapkan dalam sebuah catatan harian (diary) melalui sosial video dalam city branding Kotagede.

\section{Heritage Kotagede Dalam Sebuah Catatan Harian}

Perjalanan menelusuri Kotagede dalam observasi data menghadirkan sebuah konsep penciptaan Heritage Travelling Diary Kotagede dengan memanfaatkan potensi masyarakat setempat melalui media audio visual, berupa social video diary. Hal tersebut menjadi inspirasi untuk memvisualisasikan hasil observasi yang ada di Kotagede sebagai konsep city branding dengan menampilkan potensi heritage Kotagede.

Heritage mulai diperkenalkan ke negara-negara dalam sidang konferensi United Nations Educational, Scientific and Cultural Organitation (UNESCO) di Paris, Perancis pada16 November 1972. Para pecinta heritage Indonesia mendeklarasikan pentingnya pelestarian (conservation) warisan Indonesia
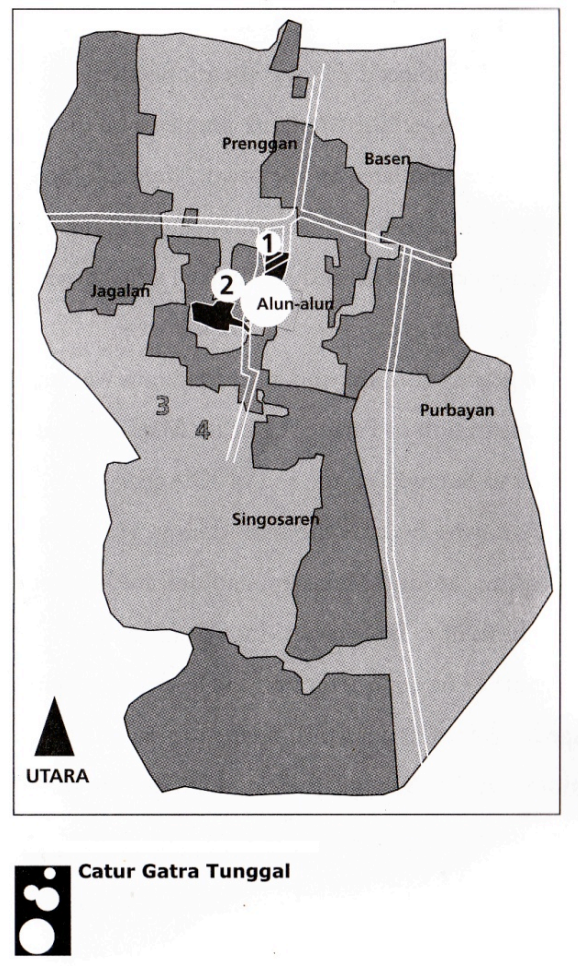

Gambar 1 Peta wilayah Kotagede yang termasuk Catur Gatra Tunggal.

Sumber: Jogja Heritage Society. Post-Disaster Conservation Manual For Kotagede Heritage District Yogyakarta, Indonesia, 2009. Hal. 9

bertepatan dengan peringatan Heritage Year 2003 bersama dengan International Council on Monuments and Site (ICOMOS) dan Kementrian Kebudayaan dan Pariwisata Indonesia. Indonesia memiliki warisan alam, pemandangan dan warian budaya. Warisan budaya terdiri dari bendawi (tangible) heritage dan non bendawi (intangible) heritage (Rahmi, 2009:15). Warian bendawi berwujud bangunan, monumen, buku, benda seni dan artefak. Warisan non bendawi berupa cerita rakyat, tradisi, bahasa dan ilmu pengetahuan.

Masyarakat Kotagede turut berperan dalam city branding, ketika potensi yang ditawarkan adalah heritage, masyarakat dituntut untuk menerima kehadiran wisatawan dengan ramah. Sehingga 
menjadikan Kotagede sebagai wisata minat khusus. Berdasarkan hasil wawancara dengan Muhammad Natsir pada tanggal 4 Februari 2012, Kotagede dibicarakan sebagai heritage setelah gempa yang terjadi di Yogyakarta pada tahun 2006 yang menyebabkan bangunan peninggalan Kerajaan Mataram Kuno hancur, sehingga banyak hal yang dapat dipelajari dari Kotagede.

Menelusuri heritage Kotagede menjadi wisata minat khusus yang digemari banyak wisatawan baik domestik maupun mancanegara saat ini. Hal tersebut berdasarkan hasil wawancara dengan Muhammad Natsir dimana Muhammad Natsir menyebut dirinya sebagai among tamu Kotagede. Pengalaman berharga bagi wisatawan baik domestik maupun mancanegara didokumentasikan melalui catatan tertulis, video, dan foto seperti sebuah catatan harian (diary).

Aksi mendokumentasikan Kotagede dari berbagai sudut pandang dilakukan oleh Muhammad Natsir bertujuan untuk memperkaya potensi wisata Kotagede yang tidak harus mengacu kepada bangunan cagar budaya kemudian mempublikasikannya melalui media jejaring sosial facebook. Berdasarkan Mitch Joel dalam Kartajaya (2010:225), "Everyone is connected, connect everyone to your businnes", langkah yang dilakukan Muhammad Natsir untuk mempublikasikan dokumentasinya, selain dapat memperkenalkan Kotagede, juga bermanfaat untuk mengetahui insight dari para pengunjung di Kotagede. Secara tidak langsung Muhammad Natsir mempromosikan Kotagede secara online selain secara offline ketika sebagai among tamu mendampingi pengunjung.
Menurut Priyo J. Salim sisi lain keunggulan dari perak Kotagede terdapat pada pahatan pengrajin dan bentuk ukiran yang tidak ada pada pengrajin perak di daerah lain. Hal ini patut untuk dipelajari dan diperkenalkan kepada masyarakat yang memiliki minat khusus terhadap kerajinan perak sehingga diharapkan tercipta pemikiran-pemikiran baru dalam melestarikan potensi kerajinan perak yang sudah ada. Potensi kerajinan perak ini menjadi salah satu acuan dalam penggalian visual untuk dimasukkan dalam cerita social video dengan konsep heritage travelling diary.

Potensi lain yang masuk dalam heritage Kotagede mengacu pada filosofi "Catur Gatra Tunggal” terlihat pada Gambar 1, merupakan konsep tata ruang yang dibangun Panembahan Senopati ketika membangun Mataram Islam. Catur Gatra Tunggal terdiri dari: keraton, alun-alun, masjid, dan pasar. Keraton sebagai pusat kekuasaan, alun-alun sebagai pusat ritual adat masyarakat, masjid sebagai pusat peribadatan, dan pasar sebagai pusat perdagangan yang menjadi satu dalam satu kawasan.

Keraton sekarang tergerus oleh perkembangan jaman menjadi pemukiman penduduk di kampung Dalem dan makam Hastorenggo yang dahulu berfungsi sebagai pusat pemerintahan. Alun-alun, yang dahulu berupa tanah lapangan sebagai pusat ritual adat masyarakat, tempat berkumpul rakyat dan raja, tetapi sekarang beralih fungsi sebagai pemukiman padat penduduk. Masjid, sebagai pusat peribadatan yang keberadaannya masih bertahan hingga sekarang dan terletak di sebelah barat kampung alun-alun dan berdampingan dengan makam. Hal ini ditekankan oleh 
Kuntowijoyo (2003:61) bahwa pembentukan kota selalu dengan pertimbanganpertimbangan sosio-kultural. Pertemuan antara golongan kelas dalam masyarakat, seperti abdi dalem dan penduduk setempat memunculkan nama-nama kampung seperti pada penamaan kampung di Kotagede. Pasar Kotagede, sebagai pusat perekonomian dan perdagangan juga masih dipertahankan oleh masyarakat Kotagede hingga saat ini, bahkan memberikan daya tarik bagi para pedagang-pedagang dari luar daerah Kotagede. Hal ini terlihat pada tradisi pasaran legi, pasar Kotagede terlihat padat oleh para pedagang yang diyakini memiliki makna bagi para pedagang untuk mendapat penghasilan yang lebih dibandingkan harihari biasa. Pasaran legi ini menjadi kebijakan pemerintahan kerajaan Mataram dahulu sebagai upaya meratakan perekonomian rakyat, sehingga tercipta hari pasaran di pasar lain di Yogyakarta, seperti pasaran pahing di pasar Sleman, pasaran pon di Pasar Gamping. Tradisi pasaran legi di Kotagede memunculkan nama pasar menjadi Pasar Legi Kotagede.

Menurut Basis Hargito, seorang penggiat kesenian rakyat di Kotagede dan pengrajin roti kembang waru, berdasarkan wawancara pada tanggal 27 Juni 2012, pasar sebagai pusat perdagangan juga menjadi tempat berkumpul masyarakat Kotagede karena di kelilingi oleh pohon waru yang meneduhkan para pedagang pada zaman kerajaan Mataram dulu. Tetapi seiring dengan perkembangan jaman, pohon waru terpinggirkan dan habis. Hal tersebut dipertegas oleh Sukarjo dalam wawancara 19 Juli 2012, bahwa renovasi pasar Kotagede sekitar 1960 menyebabkan hilangnya pohon waru.
Pohon waru juga menjadi inspirasi terciptanya roti kembang waru yang menjadi tradisi dan digunakan pada upacara adat perkawinan oleh kerajaan Mataram. Roti kembang waru disimbolkan sebagai delapan unsur dalam alam (ether), yang secara simbolis dimaknai sebagai syukur terhadap Tuhan. Roti kembang waru juga dapat dijumpai dalam tradisi gunungan kuliner dalam kirab Kotagede yang dilaksakan tiap tahun sebagai rangkaian Nguras Sendang Makam Kotagede.

Berdasarkan hasil wawancara dengan Basis Hargito roti kembang waru masuk dalam heritage Kotagede yang sudah turun temurun dilestarikan oleh masyarakat Kotagede khususnya di kampung Bumen. Roti kembang waru dimasukkan dalam social video heritage travelling diary untuk kategori kuliner khas Kotagede, kuliner yang bertahan serta masih terlihat adanya upaya masyarakat untuk memperkenalkan potensi khas kotagede ini kepada generasi muda. Salah satu contoh kegiatannya adalah lomba menghias roti kembang waru pada Minggu, 10 Juni 2012 di Pendopo Bumen yang diselenggarakan oleh komunitas Ketjil Bergerak dan Muda Mudi Bumen, Kotagede.

Kesenian Srandul merupakan kesenian rakyat yang menjadi potensi seni di Kotagede yang masih bertahan saat ini, juga menjadi salah satu materi visual dalam social video heritage travelling diary. Srandul dipentaskan dalam 3 babak dengan cerita yang berbeda dan "pating srendil" sehingga dinamakan Srandul. Srandul sebagai pertunjukan rakyat yang keberadaanya dahulu sebagai hiburan rakyat sehingga melekat di kalangan masyarakat Kotagede. 


\section{PEMBAHASAN}

Pada mind mapping city branding ini (Gambar 2), studi desain komunikasi visual dalam perancangan city branding Kotagede, menerapkan pemahaman terhadap teori brand dan teori komunikasi kognitif dalam mengkaji Kotagede sebagai objek wisata. Kotagede memiliki potensi-potensi heritage yang dapat menjadi kekuatan citra brand Kotagede terhadap masyarakat. Potensi tersebut menjadi sebuah diary bagi wisatawan terhadap pengamatan bangunan heritage dan kegiatan kesenian serta hasil kerajinan Kotagede yang bertahan secara turuntemurun. Wisata Kotagede menjadi tawaran bagi target audience yang dapat diperkenalkan melalui kegiatan promosi wisata oleh pihak-pihak terkait seperti pemerintah daerah Yogyakarta dan masyarakat Kotagede. Promosi dilakukan dengan penentuan media-media yang dekat dan langsung bersentuhan dengan audience berdasarkan consumer journey. City brand Kotagede dibangun melalui pendekatan personal branding berdasarkan karakteristik target audience.

Kegiatan city branding dalam skala kecil, kawasan dalam suatu kota yang terletak diluar batas administratif kota Yogyakarta, salah satunya Kotagede. H. J. Van Mook dalam Kuntowijoyo (2003: 61), Kotagede mulai tumbuh sebagai kota satelit tempat golongan kelas menengah. Kotagede juga membutuhkan brand berupa logo dan slogan (taglines) dibangun dengan kekuatan visual dan grafis yang berfungsi sebagai pengingat dan pembeda. Sehingga, dalam perancangan city brand Kotagede menawarkan konsep Kotagede heritage travelling diary.
Konsep perancangan media promosi wisata Kotagede menggali potensi-potensi Kotagede yang menumbuhkan rasa bangga untuk mengamati, menjelajahi, melalui naskah cerita social video bertema heritage travelling diary. Visualisasi social video menampilkan dua talent yang melakukan travelling di Kotagede. Talent pertama seorang perempuan, yang memiliki minat terhadap kerajinan perak, kuliner roti kembang waru, dan jamu di Kotagede. Sedangkan talent kedua seorang laki-laki yang memiliki minat terhadap kesenian khas Srandul Kotagede, pasar legi (pasar burung), makam, dan jamu di Kotagede.

Adegan masing-masing talent mengungkapkan apa yang dialami melalui statement atau testimoni langsung dari talent dalam social video. Konsep image atau karya yang akan dirancang pada penciptaan ini adalah menampilkan suasana Kotagede yang ramah, menyenangkan, berdasarkan tempat dan pengalaman baru mengacu pada prinsip dasar dari filosofi "Catur Gatra Tunggal” yang merupakan penggabungan empat komponen menjadi satu kesatuan. Catur Gatra Tunggal merupakan konsep tata ruang yang dibangun Panembahan Senopati ketika membangun Mataram Islam. Catur Gatra Tunggal terdiri dari: keraton, alun-alun, masjid, dan pasar. Keraton sebagai pusat kekuasaan, alun-alun sebagai pusat ritual adat masyarakat, masjid sebagai pusat peribadatan, dan pasar sebagai pusat perdagangan yang menjadi satu dalam satu kawasan.

\section{City Brand Kotagede}

Studi desain komunikasi visual dalam perancangan city branding Kotagede, menerapkan pemahaman terhadap teori 
brand dan teori komunikasi kognitif dalam mengkaji Kotagede sebagai objek wisata. Kotagede memiliki potensi-potensi heritage yang dapat menjadi kekuatan citra brand Kotagede terhadap masyarakat. Potensi tersebut menjadi sebuah diary bagi wisatawan terhadap pengamatan bangunan heritage dan kegiatan kesenian serta hasil kerajinan Kotagede yang bertahan secara turuntemurun. Wisata Kotagede menjadi tawaran bagi target audience yang dapat diperkenalkan melalui kegiatan promosi wisata oleh pihak-pihak terkait seperti pemerintah daerah Yogyakarta dan masyarakat Kotagede. Promosi dilakukan dengan penentuan media-media yang dekat dan langsung bersentuhan dengan audience berdasarkan consumer journey. City brand Kotagede dibangun melalui pendekatan personal branding berdasarkan karakteristik target audience.

Berdasarkan pendekatan kognitif, seseorang melihat sebuah obyek yang ditangkap oleh mata langsung mengambil kesimpulan mengenai persepsi melalui proses mental. Carolyn Bloomer dalam Yongky Safanayong (2006: 52-53) mengidentifikasi beberapa aktivitas mental yang dapat mempengaruhi persepsi visual: memori, proyeksi, harapan, seleksi, kebiasaan, kepentingan, ketidakcocokan, kebudayaan dan kata-kata.

Pertama, daya ingat (memory). Aktivitas mental yang penting keterlibatannya dalam persepsi visual adalah memory. Memory merupakan hubungan dengan semua image yang pernah dilihat. Mnemonics adalah pemakaian gambar sebagai bantuan ingatan digunakan untuk membantu mengingat kembali peristiwa atau cuplikan verbal.
Kedua, proyeksi. Orang-orang kreatif dapat melihat bentuk-bentuk seperti awan, pohon, batu-batuan, keadaan mental seseorang diproyeksikan ke obyek mati. Perbedaan antara orang yang bisa melihat dan tidak terlihat pada proses mental mempengaruhi apa yang mereka lihat.

Ketiga, penseleksian (selectivity). Persepsi visual adalah sebuah aktivitas di bawah sadar secara otomatis dimana image dalam jumlah besar masuk dan keluar dari benak tanpa diproses. Benak terfokus hanya pada detik yang penting atau signifikan dalam suatu adegan.

Keempat, kebiasaan (habituation). Benak seseorang cenderung tidak memperhatikan hal-hal pada rute yang kita lewati setiap hari, manusia lebih suka melewati daerah baru yang lebih menarik. Tetapi apabila stimulasi berlebihan dapat menyebabkan culture shock, yang menyebabkan iritasi dan kelelahan, apabila melihat sensasi visual berlebihan yang harus disaring otak. Salah satu cara untuk menjaga agar benak tidak terpuruk kebiasaan (habit) adalah mencari cara-cara baru berpikir tentang hal-hal biasa. Berlatih berpikir kreatif mempersiapkan benak kita untuk berpikir secara aktif tentang imageimage baru.

Kelima, penonjolan atau kepentingan (salience). Suatu rangsangan akan lebih diperhatikan kalau mengandung arti tertentu bagi seseorang. Keenam, hiruk pikuk atau ketidakcocokan (dissonance). Benak seseorang hanya terbatas dapat berkonsentrasi pada satu aktivitas. Terlalu banyak pesan visual yang disajikan sekaligus akan menyebabkan hiruk pikuk (dissonance).

Ketujuh, budaya (culture). Perilaku manusia, cara berbicara, makan, minum, 
kelakuan sosial, beragama, pengaruh budaya, mempunyai pengaruh yang kuat pada persepsi visual, kebudayaan tidak hanya konsep batasan sebuah negara atau ide budaya tinggi. Kebudayaan meliputi etnik, gender, umur, orientasi sex, bentuk fisik, lokasi geografis dan aspek-aspek lain kehidupan manusia. Kebudayaan juga menentukan pentingnya sign yang mempengaruhi manusia yang tinggal didalamnya.

Delapan, kata-kata (words). Meskipun manusia melihat dengan mata, akan tetapi pikiran manusia terdiri dari kata-kata, daya ingat dan kebudayaan sangat berpengaruh pada pemahaman dan ingatan manusia. Salah satu bentuk komunikasi yang kuat adalah apabila kata-kata dan gambar digabung didalam proporsi yang seimbang.

Nama brand, dan taglines, slogan, atau frase khas pendek yang digunakan untuk mengidentifikasi dan mempromosikan sebuah produk. Visual utama dari diferensiasi adalah logo yang merupakan landasan identitas visual, didukung dengan elemen grafis yang berkontribusi pada identitas visual atau program branding. Ketika brand adalah hal pertama yang diperkenalkan kepada publik, nama merek, logo, dan kemasan membentuk identitas brand.

Identitas sebuah brand merupakan hal yang nyata dan menarik bagi indera. Calon konsumen dapat melihat, menyentuh, mendengar, dan melihat brand tersebut bergerak. Identitas brand menguatkan diferensiasi, membuat ide-ide besar dan makna secara mudah untuk diakses. Identitas brand mengambil elemen berbeda dan disatukan ke dalam sistem secara keseluruhan. Ketika sebuah kota telah memiliki positioning brand yang kuat, yang menikmati hasilnya tentu saja seluruh masyarakat kota, termasuk pemerintah dan swasta. Pengertian city brand menurut Mendiola Budi Wiryawan (2008: 45), "Kumpulan persepsi, ide, impresi seseorang atau sekelompok orang terhadap sebuah kota (misalnya tentang produk, jasa, alam lingkungan, seni budaya, dsb). Kegiatan terencana dan terpadu dalam membangun brand sebuah kota."

Berbagai potensi yang ada di Kotagede yang sudah dipaparkan sebelumnya, seperti arsitektur (Catur Gatra Tunggal/konsep tata ruang) kerajinan perak, kuliner, dan kesenian menjadi hal yang melatarbelakangi atau sebagai acuan visual terciptanya landmark Kotagede pada proyek studio penciptaan seni oleh penulis beserta mahasiswa desain komunikasi visual Pasca Sarjana ISI Yogyakarta: Agus Budi Setiawan, Adita Ayu Kusumasari, dan Septi Asri Finanda, serta pengolahan tipografi oleh Ipung Kurniawan (Gambar 3).

Kekuatan landmark Kotagede terdapat pada visual yang mengolah ikon-ikon berdasarkan potensi Kotagede di bidang kerajinan, kesenian, arsitektur dan kuliner. Ide dasar dari bentuk daun waru yang muncul mendominasi dari ikon-ikon visual ke-empat potensi, disatukan dengan bentuk geometris persegi dari unsur atap bangunan tradisional jawa yang banyak terdapat di kawasan Kotagede. Landmark Kotagede akan diolah dengan menambahkan tagline sekaligus menjadi konsep logo Kotagede sebagai brand identity.

Tetapi sebuah brand kota belum lengkap tanpa adanya tagline yang melekat pada logo. Pesan dalam tagline tidak hanya berupa kata 
yang didapatkan berdasar kepada fungsi sebuah kota. Kata dalam tagline tersebut harus memiliki makna yang mendalam (beyond the word).

Sebuah kata dalam tagline brand kota harus memiliki emosi yang dapat mencitrakan kota dengan kuat dan dapat menyentuh hati audience serta mudah melekat di benak target audience. Tagline Kotagede digali berdasarkan nilai yang berkembang di masyarakat Kotagede, sesuatu yang dirasakan oleh masyarakat, baik warga Kotagede maupun pengunjung di Kotagede terhadap Kotagede.

Tagline Lovely merupakan pernyataan atau ungkapan. Kesederhanaan dalam tagline yang dipilih dengan satu kata bahasa Inggirs, dimaksudkan bahasa Inggris merupakan bahasa yang universal, digunakan oleh sebagian besar negara-negara. Hal ini bertujuan dalam target penyampaian citra Kotagede dapat menjangkau masyarakat dunia.

\section{Video Diary}

Video diaries berkembang di masyarakat berdasarkan dukungan teknologi camcorder yang semakin terjangkau. Masyarakat dapat mengekspresikan pandangan secara pribadi terhadap obyek yang dilihat. Atmaja, dkk (2007: 148) disebutkan bahwa media audio visual ternyata efektif dan mampu digunakan oleh masyarakat untuk keperluan dan tujuan mereka sendiri. Dokumenter sering dianggap sebagai rekaman dari "aktualitas", potongan rekaman sewaktu kejadian sebenarnya berlangsung, saat orang yang terlibat di dalamnya berbicara, kehidupan seperti apa adanya, spontan, dan tanpa media perantara.
Menurut Muhammad Natsir, hal pertama yang harus diketahui oleh pengunjung adalah pasar Kotagede. Hal tersebut diperkuat Heddy Shri Ahimsa-Putra dalam seminar City Colourful, 12 Mei 2012 di Universitas Gadjah Mada yang menyebutkan bahwa untuk menggali nilai atau roh suatu kota, hal pertama yang harus dilakukan adalah berkunjung ke pasar tradisional di daerah itu.

Hal ini yang mendasari salah satu ide awal dari cerita dalam social video heritage travelling diary Kotagede dari suasana pasar dan berakhir kembali di pasar (Gambar 4). Akhir dari cerita ini di seputar pedagang jamu pasar yang menjadi kekhasan pasar Kotagede serta lokal content Kotagede yang menurut pengageng abdi dalem makam Bapak Slamet, jamu kunir asem merupakan salah satu warisan potensi kuliner Kotagede.

Kegiatan travelling sering dilakukan oleh wisatawan dengan berjalan kaki, bersepeda, menggunakan kendaraan bermotor maupun sarana transportasi lain yang biasa ditawarkan oleh jasa-jasa travel. Namun perjalanan atas kehendak sendiri (independent travelling) juga banyak dilakukan oleh wisatawan. Mereka ingin menentukan tujuan perjalanannya sendiri dan tidak ingin dibatasi oleh waktu kunjungan.

Observasi dengan cara travelling oleh penulis di Kotagede, lalu menemukan suasana, event, dan lokasi yang menarik/eksotis sebagai kekuatan heritage di Kotagede. Pengalaman dalam travelllig pribadi memunculkan interpretasi terhadap Kotagede yang menimbulkan pertanyaanpertanyan tentang Kotagede, masyarakat, dan pengalaman. Pada pengamatan dalam observasi, menjadi dasar dalam penetapan target audience. Namun penetapan wilayah 
jangkaun target audience meluas karena kosep social video dengan jejaring sosial.

Bentuk diary yang didokumentasikan oleh wisatawan dapat memberi keuntungan dari pembangunan sebuah brand ketika menjadi sebuah obrolan (word of mouth) yang dapat ditemui pada jejaring sosial. Rute perjalanan memasuki kampung-kampung di Kotagede yang memiliki potensi-potensi heritage memberikan minat khusus dalam kegiatan travelling sehingga menarik untuk divisualkan dan dikemas, menjadi inspirasi dalam kegiatan promosi city brand Kotagede, karena akan lebih mendekatkan brand secara personal kepada masyarakat terhadap image Kotagede.

Konsep penggarapan social video meliputi pembuatan narasi video untuk penghantar ungkapan perasaan terhadap gambar-gambar adegan dan obyek lokasi dalam video. Menggunakan subtitle bahasa Inggris dikarenakan social video yang dirancang akan dimasukkan pada media jejaring sosial youtube. Durasi penayangan terbagi dalam 3 versi yaitu setiap 1 menit untuk cerita masing-masing talent dan penggabungan cerita kedua talent dengan durasi 3 menit di mana kemunculan logo sebagai bagian dari brand pada social video yang dirancang tidak hanya menempel pada gambar tetapi juga sebagai atribut di dalam cerita yang bertujuan untuk menancapkan identitas visual.

Pembagian cerita social video disesuaikan dengan adegan talent yang terdiri dari 2 orang talent sebagai pelaku travelling dengan masing-masing minat yang ada di Kotagede (Gambar 5). Pada akhir adegan di singgung dengan suatu pernyataan dan pertanyaan (clif hanger) yang menggantung ditujukan kepada target audience untuk memancing keingintahuan audience dimana penghubung dari kedua talent yang berbeda untuk mengarahkan pada pesan atau tagline yang mengikuti logo Kotagede yang muncul di tengah adegan dan muncul kembali di akhir cerita (Gambar 6). Penempatan alamat situs (mandatories) Kotagede sebagai call action bagi audience untuk mendapat informasi yang lebih jauh mengenai Kotagede.

Video Heritage Travelling Diary Kotagede di-publish melalui media jejaring sosial youtube (Gambar 7) dengan pemilihan adegan dalam gambar yang mewakili identitas Kotagede, sehingga dipilih pada frame adegan bangunan Makam Raja Mataram yang terdapat sebuah gunungan kuliner dengan bendera merah putih sebagai ikon mewakili Kotagede berada di negara Indonesia. Youtube memiliki jangkauan tayang yang luas hingga ke mancanegara, sehingga subtitle dalam bahasa Inggris digunakan pada setiap narasi berbahasa Indonesia untuk membantu para pemirsa yang kurang mengerti arti kata pada narasi, sehingga diharapkan pesan yang akan disampaikan dapat dimengerti. Judul video menggunakan nama Kotagede Lovely untuk mengarahkan pemirsa youtube pada kelompok video-video lain tentang Kotagede, sehingga diharapkan citra Kotagede dengan tagline Lovely dapat menancap di benak target audience.

Media jejaring sosial facebook dipilih untuk menyebarkan video Heritage Travelling Diary Kotagede dengan memanfaatkan hubungan relasi yang juga memiliki minat terhadap Kotagede seperti ke facebook milik Muhammad Natsir, Priyo J. Salim, serta dari kalangan akademik sehingga dapat membantu dalam penyebaran ke pengguna 
jejaring sosial facebook lainnya (Gambar 8). Adanya diskusi, pendapat, maupun kritikan dari video ini akan menjadi salah satu strategi marketing dengan word oh mouth, dan brand Kotagede semakin diketahui oleh masyarakat.

\section{KESIMPULAN}

Audio visual merupakan media yang menguntungkan dalam menggambarkan keistimewaan potensi suatu kawasan dalam upaya city branding Kotagede. Video dengan konsep travelling diary mampu menampilkan keberagaman Kotagede serta menjadi kebebasan ekspresi dalam mengungkap citra yang diperoleh ketika berada di Kotagede. Adanya potensi-potensi heritage di antaranya peninggalan sejarah kerajaan Mataram berupa bangunan makam, kerajinan perak, kampung, kesenian Srandul, dan roti Kembang Waru, menjadikan Kotagede sebagai tempat yang memiliki kekhasan dan menjadi daya saing terhadap kota lain.

Pada tahapan proses perancangan social video guna mendukung promosi Kotagede ini, mendalami insight masyarakat di dalam dan di luar Kotagede sangat penting dengan mempelajari lintas bidang ilmu terkait brand, perkotaan dan sosial media. Pengembangan ide cerita dalam promosi ini, menyerap pengalaman-pengalaman warga Kotagede yang memunculkan kebanggaan terhadap potensi heritage Kotagede. Adanya penambahan narasi video secara audio dan visual berupa teks mampu mengarahkan pesan yang dimaksud terhadap pemirsa dalam menggiring memori-memori dari tiap adegan, lalu menjadi satu pesan pada akhir cerita dengan penambahan tagline Kotagede dan alamat web yang bisa dikunjungi oleh target audience. Website berisi informasi- informasi tentang Kotagede berupa video diary, serta dokumentasi kegiatan-kegiatan masyarakat Kotagede dengan tampilan seperti blog diary Kotagede. Adanya website menjadi bagian dari kampanye melalui media internet yang akan membuat target audience merasakan suasana dengan tema diary serta menimbulkan brand experience yang positif.

Social video dalam jejaring sosial memberi keuntungan terhadap luasnya jangkauan sehingga harus terpikirkan bahasa yang dipilih dalam narasi video. Social video merupakan sarana yang dapat mendukung dalam kegiatan Public Relation dalam upaya mempublikasikan Kotagede. Branding Kotagede berdasarkan filosofi tata kota "Catur Gatra Tunggal" diperlukan pengetahuan sejarah yang runut serta diskusi secara fokus terhadap target audience dan masyarakat Kotagede.

Gagasan-gagasan baru diharapkan terus muncul dalam membangun city brand dari pengalaman-pengalaman ketika melakukan travelling.

\section{DAFTAR PUSTAKA}

[1] Budi Santosa, Revianto dan Tri Atmojo, Bambang. 2007. Kotagede, Life Between Walls. Jakarta: PT. Gramedia Pustaka Utama

[2] Iswati, Tri Yuni. 2009. Kampung Dalem Dibalik Kemegahan Kotagede. Surakarta: UNS Press.

[3] Rahmi, Dwita Hadi \& Titi Handayani. 2009. Post-Disaster Conservation Manual For Kotagede Heritage District Yogyakarta, Indonesia. Yogyakarta: Jogja Heritage Society.

[4] Kartajaya, Hermawan. 2010. Connect! Surfing New Wave Marketing. Jakarta: PT Gramedia Pustaka Utama. 
[5] Kuntowijoyo. 2003. Metodologi Sejarah edisi kedua. Yogyakarta: PT Tiara Wacana.

[6] Riyadi, Muammad Fuad. 2001. Kampung Santri, Tatanan Dari Tepi Sejarah.Yogyakarta: Ittaqa Press.

[7] Safanayong, Yongki. 2006. Desain Komunikasi Visual Terpadu. Jakarta: Arte Intermedia.

[8] Wiryawan, B. Mendiola. 2008. Kamus Brand A-Z. Jakarta: Red \& White Publishing.

\section{Wawancara}

Wawancara dengan Basis Hargito (67th), seniman (penggiat seni) dan pengusaha roti Kembang Waru, wawancara tanggal 27 Juni 2012 di kampung Bumen, RT 23 RW 6, Kelurahan Purbayan, Kotagede, Yogyakarta, Indonesia.

Wawancara dengan Muhammad Natsir (51th), pengangguran, wawancara tanggal 4 Februari 2012 dan di Pekaten KG II 850 RT 45 RW IX Prenggan, Kotagede, Yogyakarta, Indonesia, 55172.

Wawancara dengan Priyo J. Salim (51th), pengusaha kerajinan perak Priyo Salim Silver Jewelry, wawancara tanggal 28 Juni 2012 di Kebohan KG 3/547, Kotagede, Yogyakarta, Indonesia, 55173.

Wawancara dengan Sukarja (64 th), warga Kotagede, wawancara tanggal 19 Juli 2012 di kampung Jagungan, Kelurahan Purbayan, Kotagede, Yogyakarta.

\section{Lampiran}

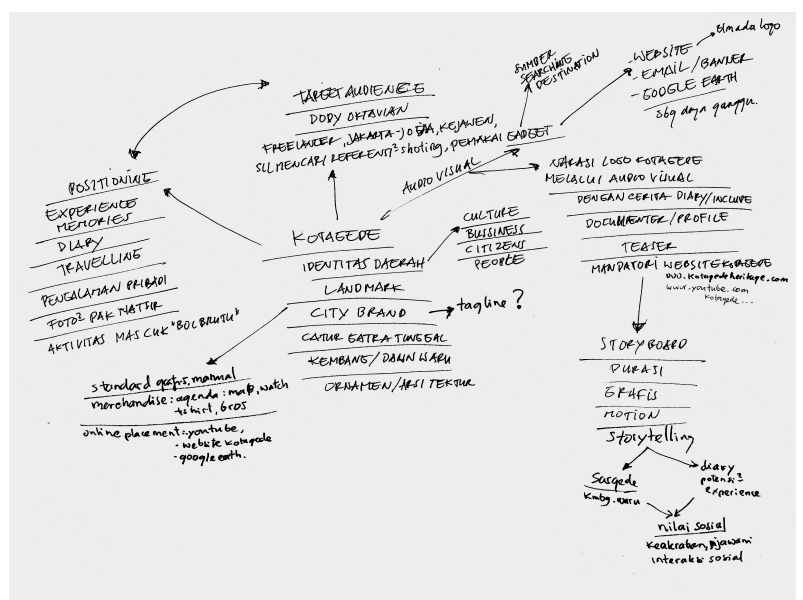

Gambar 2 Mind Mapping dalam perancangan city branding Kotagede.

Sumber: Dokumentasi Penulis, 2012.

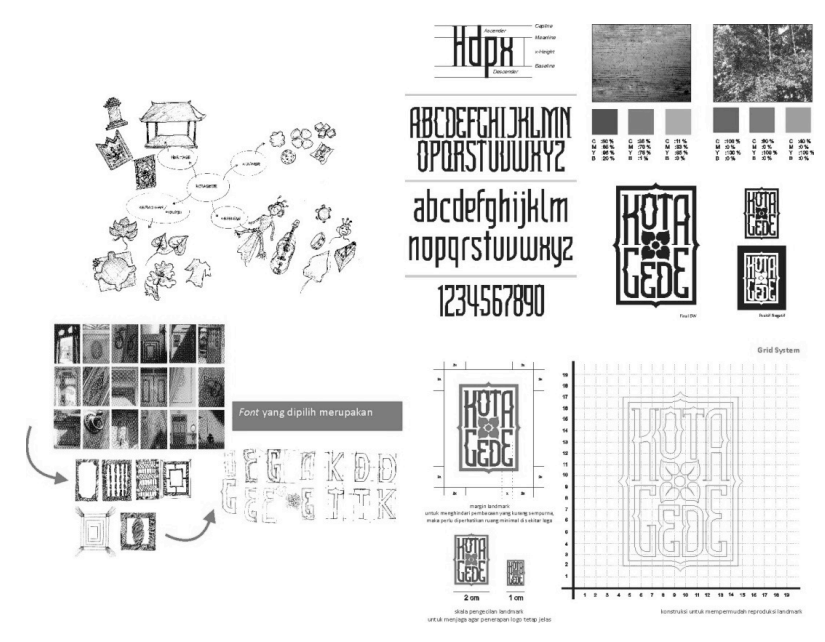

Gambar 3 Proses Perancangan Landmark Kotagede. Sumber: Dokumentasi Penulis, 2010. 


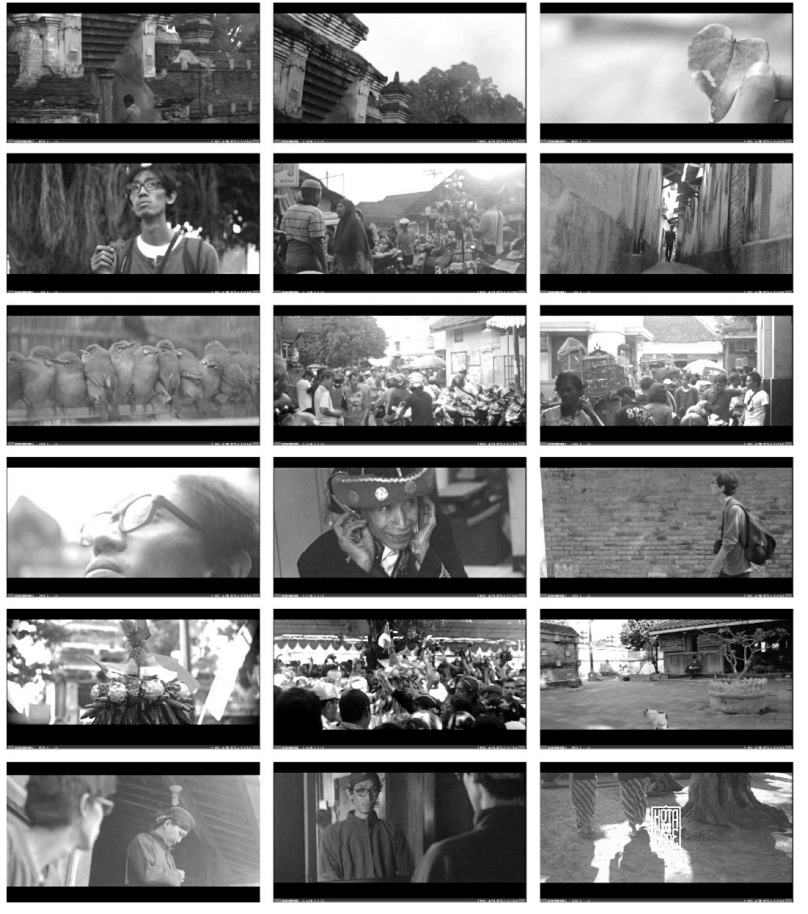

Gambar 4 Adegan awal suasana di Pasar Kotagede oleh talent 1 pada sequen 1 .

Sumber: Dokumentasi Penulis, 2012
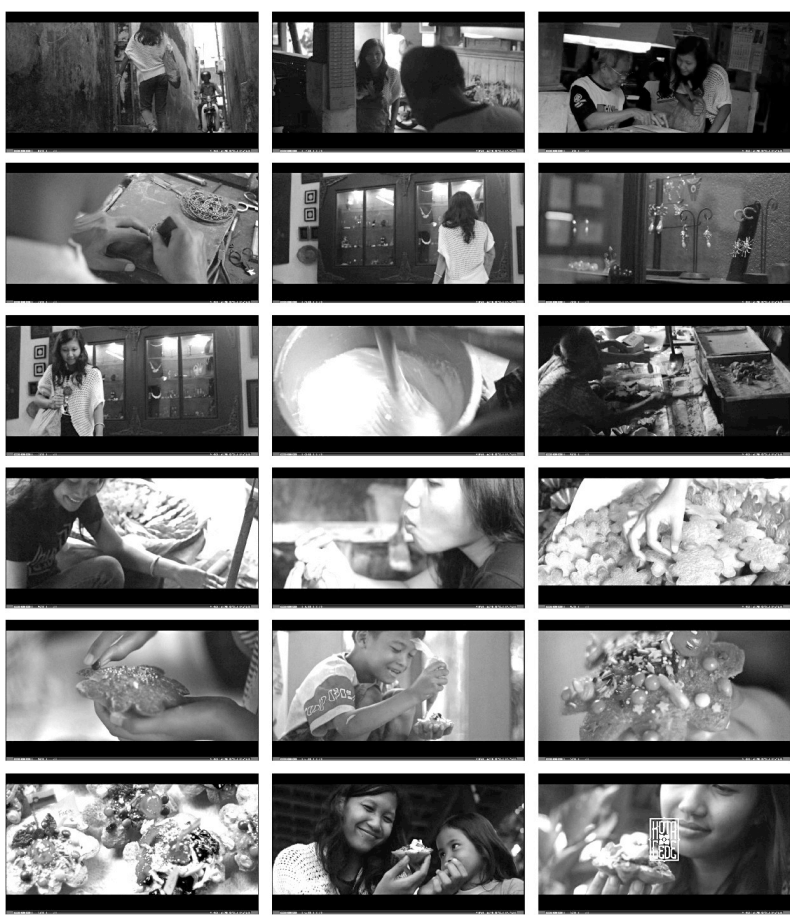

Gambar 5 Adegan suasana di pengrajin perak Kotagede oleh talent 2 pada sequen 2 .

Sumber: Dokumentasi Penulis, 2012

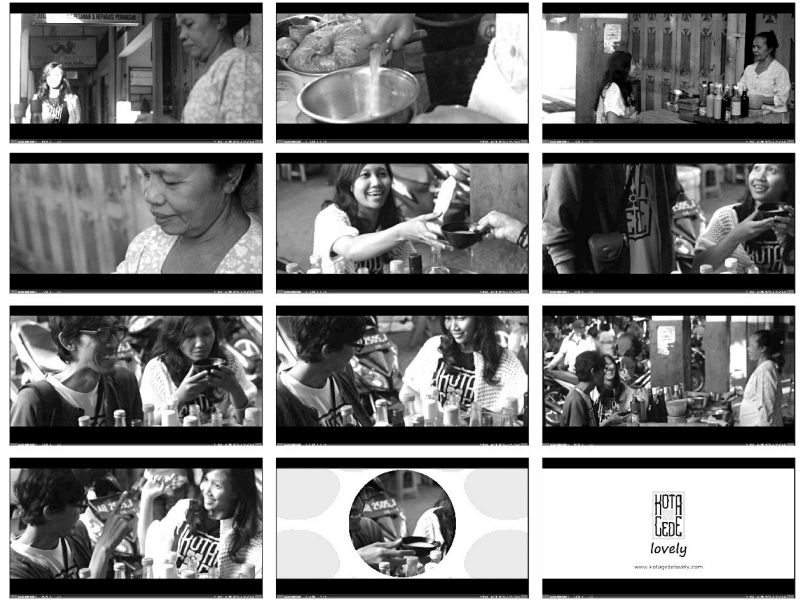

Gambar 6 Adegan dalam video Kotagede Lovely. Sumber: Dokumentasi Penulis, 2012

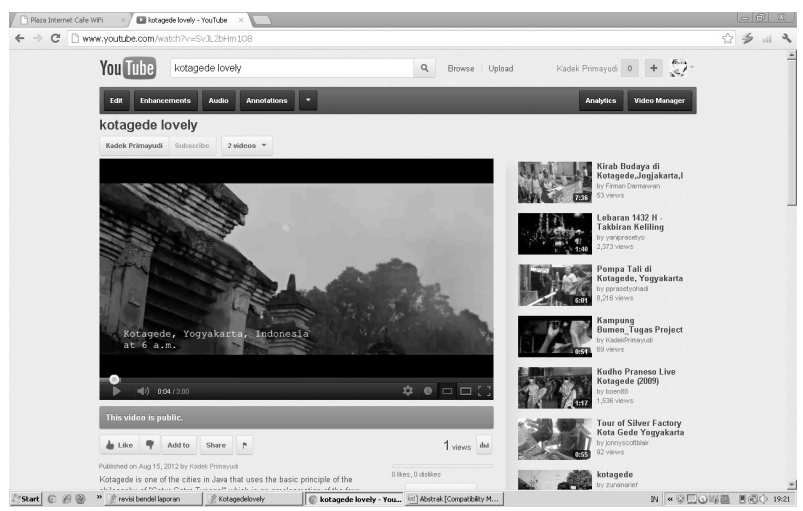

Gambar 7 Penayangan Video berjudul Kotagede Lovely dengan konsep Heritage Travelling Diary dalam media sosial youtube.

Sumber: Dokumentasi Penulis, 2012

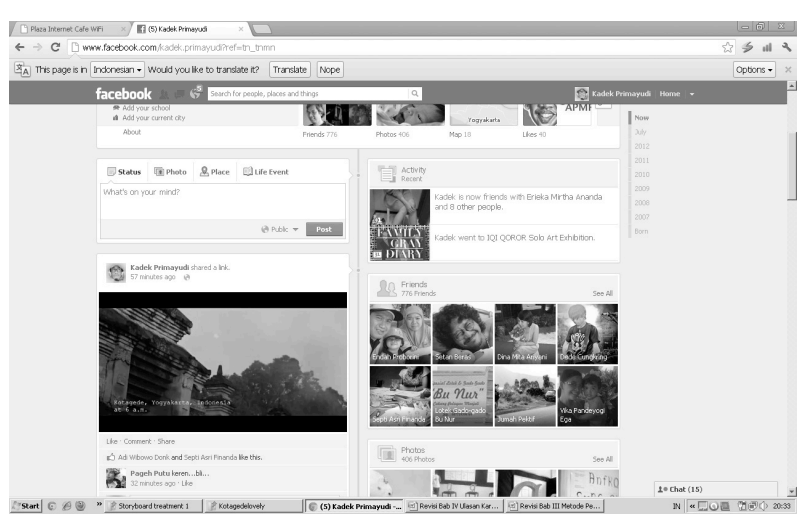

Gambar 8 Penayangan Video berjudul Kotagede Lovely dengan konsep Heritage Travelling Diary dalam facebook.

Sumber: Dokumentasi Penulis, 2012 
